\title{
ABSOLUTE DATING OF THE BRONZE AGE DEFENSIVE SETTLEMENT IN HORODNIANKA (NE POLAND)
}

\author{
Marek Krąpiec ${ }^{1,2} \cdot$ Monika Bolka ${ }^{1}$ Jerzy Brzozowski ${ }^{3}$
}

\begin{abstract}
In 2008-2009, during construction of the ring road around the town of Sztabin in NE Poland, archaeological rescue excavations were carried out at site no. 12 in Horodnianka. The excavations revealed the remains of a defensive settlement from the Bronze Age, with a total surface of 3 ha. Concentric wooden palisades reinforcing the settlement were situated on sandy, elevated embankments of the Biebrza River. Altogether, 189 samples of archaeological wood, mainly oak (Quercus sp.), were collected. Dendrochronological analysis demonstrated that the trees were cut down within a relatively short period of only $22 \mathrm{yr}$. On the basis of 22 contemporaneous dendrochronological sequences, the average curve HOR_AAl ( $89 \mathrm{yr}$ long) was constructed. However, attempts at dating the average curve against the chronologies from adjacent areas were unsuccessful. Therefore, determination of the time interval represented by the palisade oaks was attempted with the wiggle-matching method. Radiocarbon dating using liquid scintillation counting (LSC) was conducted for 6 suitable samples selected from the average curve. The ${ }^{14} \mathrm{C}$ results, after calibration, suggest the dates of cutting the oaks outlining the Horodnianka chronology most probably fall in the time interval $870-795$ cal BC. This means that Horodnianka could be the furthest northeastern defensive fortification of the Lusatian culture.
\end{abstract}

\section{INTRODUCTION}

In 2008-2009, during construction of the ring road around the town of Sztabin in NE Poland, rescue excavations were carried out at site no. 12 in Horodnianka. From a cultural point of view, this site turned out to be remarkably diversified. The excavations unveiled remains of a defensive settlement from the Bronze Age, which stretched over a surface of 3 ha. Archaeological investigations, however, were restricted to an area only slightly over half a hectare. The excavations carried out resulted in an inventory of over 50,000 historical and/or prehistoric objects (Bednarz and Brzozowski 2009). Timbers from the palisades strengthening the settlement were subjected to dendrochronological and radiocarbon dating. Thus far, there is no evidence of Lusatian culture settlement in the region.

\section{ARCHAEOLOGICAL INVESTIGATIONS}

The site Horodnianka was discovered during a survey as a part of the program "Archaeological Pattern of Poland." The rescue excavation investigations were preceded by surveys located on the area of the planned ring road around the town of Sztabin (Brzozowski et al. 2008). The investigated area is relatively flat, with peat layers 20 to $270 \mathrm{~cm}$ thick, lying on river-type and/or fluvioglacial sands. The site is located on the left bank of the Biebrza River, in an area of periodically flooded meadows. The excavation was carried out manually, removing $10-\mathrm{cm}$ layers at a time, and allowed to distinguish 2 rather extensive settlements with economic and defensive functions. The settlements consisted of internal buildings surrounded with multiple palisade walls enclosing an area $\sim 30-40 \mathrm{~m}$ in diameter, and an external palisade, which enclosed an area $\sim 150 \mathrm{~m}$ in diameter. The excavations conducted examined both vast internal structures. The findings included ubiquitous flints, pieces of ceramics, bones, timbers, as well as stones, slag, and pugging (Bednarz and Brzozowski 2009).

\footnotetext{
${ }^{1}$ Dendrochronological Laboratory, Faculty of Geology, Geophysics and Environmental Protection, AGH - University of Science and Technology, Al. Mickiewicza 30, 30-059 Kraków, Poland.

2Laboratory of Absolute Dating, Cianowice 225, 32-043 Skała, Poland. Corresponding author. Email: mkrapiec@agh.edu.pl.

${ }^{3}$ Regional Museum in Suwałki, T. Kościuszki 81, 16-400 Suwałki, Poland.
}

(C) 2012 by the Arizona Board of Regents on behalf of the University of Arizona

Proceedings of the 6th International Radiocarbon and Archaeology Symposium, edited by E Boaretto and N R Rebollo Franco RADIOCARBON, Vol 54, Nr 3-4, 2012, p 993-1001 


\section{MATERIALS}

This study deals with the archaeological timbers discovered during rescue excavations at site no. 12 in Horodnianka (Figure 1). The wood samples were taken from concentric palisades reinforcing and protecting the settlements, situated on sandy heights of the Biebrza River. Fragments of the uncovered palisade are presented in Figure 2. The excavation area is characterized by high groundwater level due to its proximity to the Biebrza River. Therefore, the wood has been relatively well preserved (with undisturbed tree ring structure), enabling dendrochronological analysis. The material was collected in 2008-2009 by the staff of the Regional Museum in Suwałki, directed by J Brzozowski. Altogether, 189 samples of archaeological timbers were subjected to dendrochronological and ${ }^{14} \mathrm{C}$ analyses. The choice for sampling material for the analyses largely depended on the kind and state of preservation of the structure. In many cases, cross-sections (entire circles, up to $\sim 5 \mathrm{~cm}$ thick) were cut out with a motor-driven saw. Timbers with traces of processing and small twigs were collected as well. Unfortunately, in most cases the timbers represented trunks and boughs of relatively young trees (143 samples), exhibiting only a dozen or so annual growth rings.

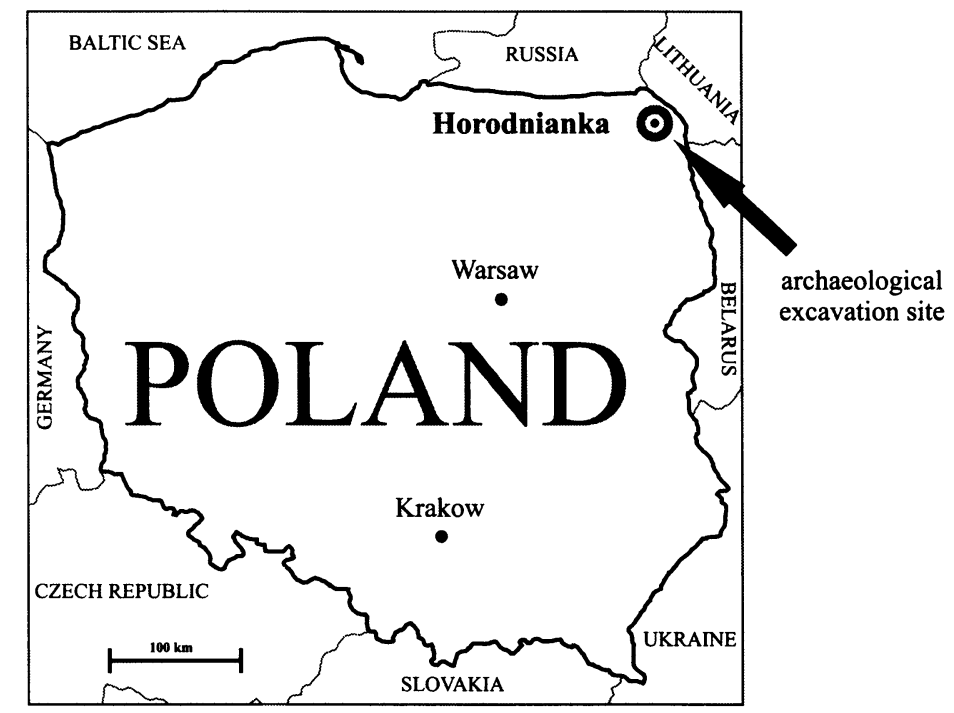

Figure 1 Location of the rescue excavations in Horodnianka, NE Poland

\section{METHODS}

Measurements of annual growth width, with 0.01-mm accuracy, were made using the DENDROLAB 1.0 apparatus in the Dendrochronological Laboratory of the AGH, University of Science and Technology in Kraków (Poland). The measurements were registered and the annual growth sequences were graphically presented using the Quercus program (Walanus 2005). Pearson's coefficient of the linear correlation $r$ and the value $t$ (Baillie and Pilcher 1973) were calculated with the software TREE-RINGS (Krawczyk and Krapiec 1995) and COFECHA (Holmes 1999). When identifying the best fitting positions of the individual sequences, high values of $r$ and $t$ were considered, as well as visual resemblance to the dendrochronological curves.

${ }^{14} \mathrm{C}$ dating using liquid scintillation counting (LSC) was performed in the Laboratory of Absolute Dating in Skała (Poland). The wood was chemically pretreated with the acid-alkali-acid (AAA) method. The procedure includes the standard synthesis of benzene from carbonized wood samples 


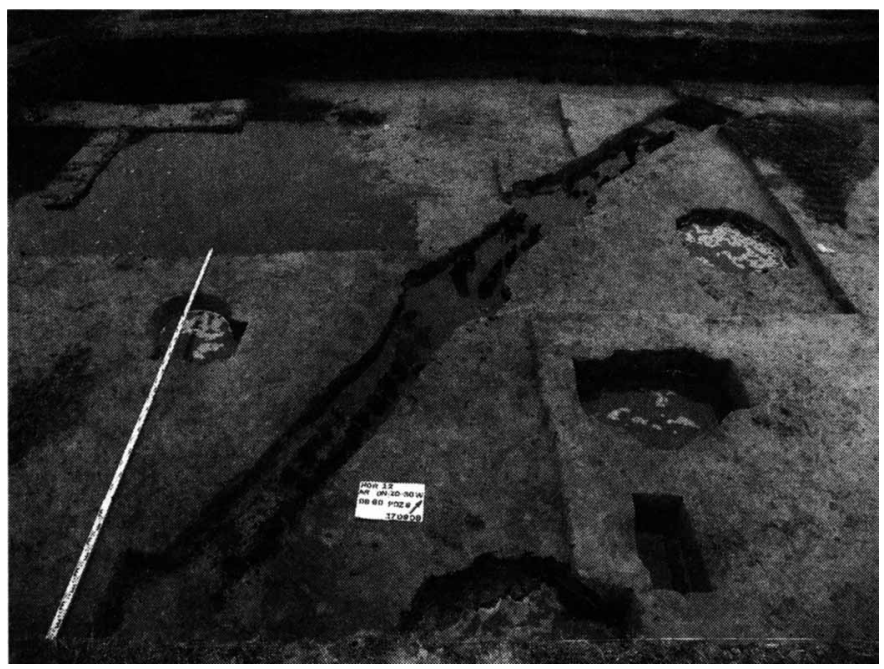

Figure 2 Remains of the Bronze Age defensive settlement in Horodnianka

(Skripkin and Kovalyukh 1994). ${ }^{14} \mathrm{C}$ measurements were carried out with a 3-photomultiplier spectrometer, the HIDEX 300SL (see Krapiec and Walanus 2011 for details).

Since the age of wood relatively dated with the dendrochronological method had to be determined independently, the wiggle-matching method was applied. The wiggle-matching technique, together with its mathematical assumptions, is described well by Bronk Ramsey et al. (2001). The method of fitting curves allows for age determination of the chronology with a precision considerably higher than individual ${ }^{14} \mathrm{C}$ dates (Pearson 1986). In this work, wiggle-matching analysis was performed with the program OxCal v 4.1.3 (Bronk Ramsey et al. 2001; Bronk Ramsey 2009) and the calibration curve IntCal09 (Reimer et al. 2009). Seven samples from selected fragments of the tree-ring sequences were relatively dated dendrochronologically. The D_Sequence model of OxCal with defined gaps was employed to account for almost the final tree rings of the oak chronology. The gap was a precisely known interval between the center of the relatively dated tree-ring series submitted for ${ }^{14} \mathrm{C}$ dating. The best match between the calibration curve and tree-ring data was calculated using the agreement index $\mathrm{A}$, which indicates the extent to which the posterior distribution overlaps with the individual ${ }^{14} \mathrm{C}$ distributions in a similar way to a $\chi^{2}$ test (Bronk Ramsey et al. 2001). Additionally, a series of dating tests was made for several wood samples, which were not included in the chronology, in order to check whether they represent the same time interval. Their conventional ${ }^{14} \mathrm{C}$ ages were then calibrated to calendar ages using OxCal.

\section{RESULTS}

This study was aimed at establishing the absolute chronology of the Horodnianka site, through dendrochronological and ${ }^{14} \mathrm{C}$ dating of the wooden palisades that defended and reinforced the settlement. Results of the wood anatomical analysis, together with the percentage of individual tree species gathered during the archaeological investigations in Horodnianka, are presented in Figure 3. Among the examined wood samples, oak (Quercus sp.), pine (Pinus sylvestris), and alder (Alnus sp.) predominated. Less frequent were ash (Fraxinus excelsior), maple (Acer sp.), spruce (Picea abies Mill.), elm (Ulmus sp.), and willow (Salix sp.). 


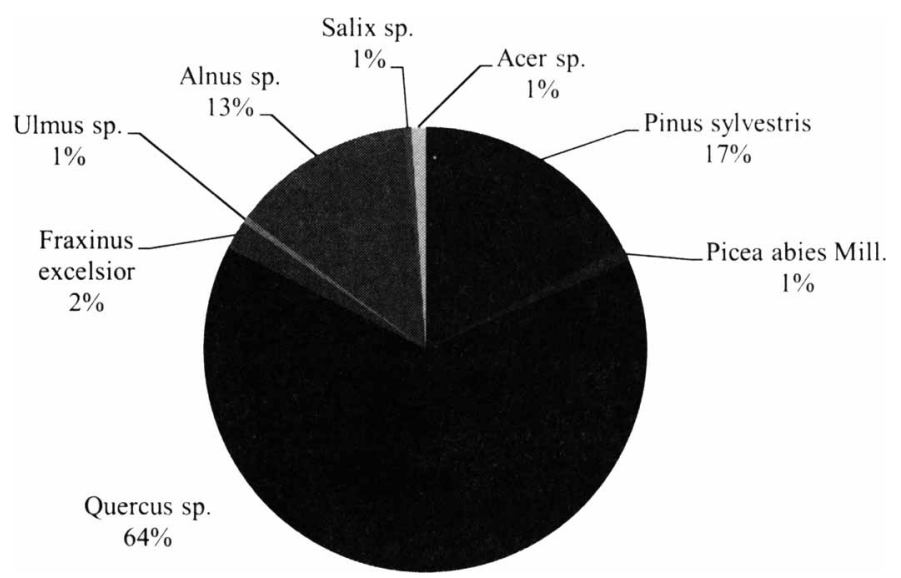

Figure 3 Anatomical analysis of wood from Horodnianka site

Of the 189 wood fragments collected, only 46 samples complied with the dendrochronological requirements. The samples chosen were well preserved enough to allow clear identification of the ring structure. They also contained an adequate number of readable tree rings, with no less than 24 annual increments. Measurements of annual growth width were made for 39 oak elements, 3 of pine, 3 of ash, and 1 of elm. In 36 samples, the last bark ring was preserved, which allowed to identify the season in which the trees were felled. Most of the oakwood (34 samples) retained the sapwood.

The tree-ring measurements resulted in annual growth sequences from 25 to $147 \mathrm{yr}$ in length. The measured samples usually contained between 25 and 50 annual increments (Figure 4). Computer correlations and visual comparisons of the curves allowed identification of trees that grew contemporaneously. On the basis of 22 cross-dated dendrochronological sequences of oak, the HOR_AA1 chronology was outlined, spanning $89 \mathrm{yr}$ (Figure 5). Values of the coefficients $t$ and $r$, reflecting the similarity between the chronology and the individual samples included in its composition, are presented in Table 1. Cross-correlation of the remaining sequences against the HOR_AA1 chronology allowed for relative dating of 10 further samples. This way, 32 total contemporaneous dendrochronological series were dated.

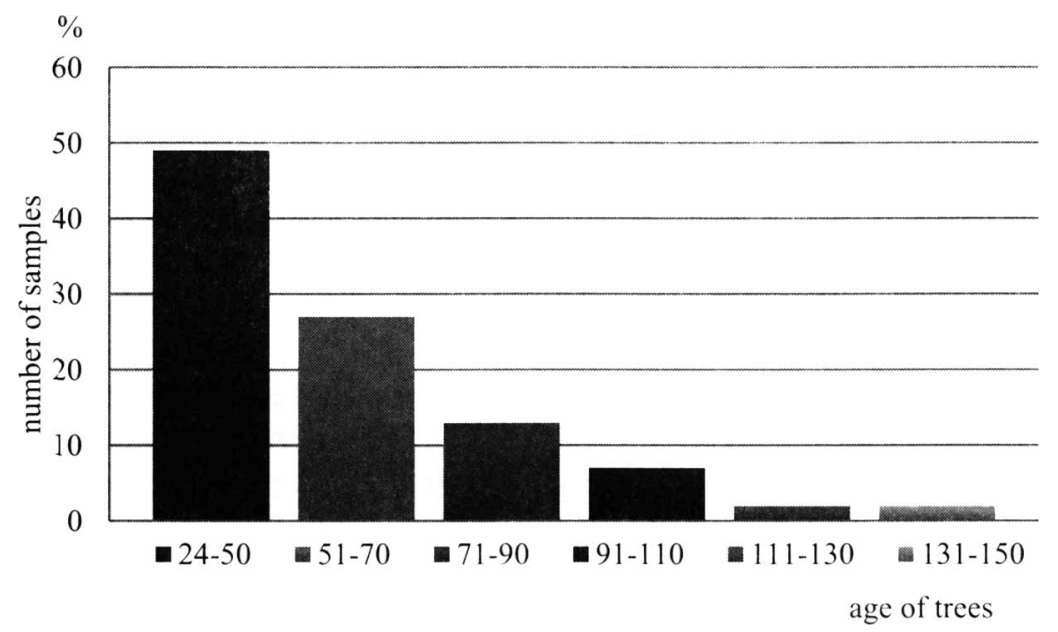

Figure 4 Percentage of 20-yr age ranges of trees used in dendrochronological analysis 


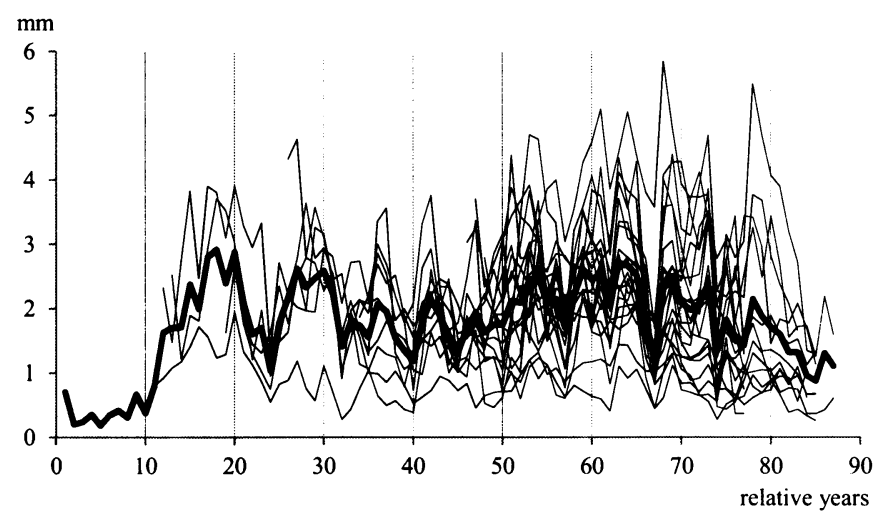

Figure 5 The chronology HOR_AA1 with individual sequences included

Table 1 Selected statistic parameters of each sequences against the site chronology.

\begin{tabular}{llll}
\hline Lab code & $\begin{array}{l}\text { Nr of } \\
\text { years }\end{array}$ & $\begin{array}{l}\text { Correlation with chronology } \\
\text { HOR_AA1 }[t]\end{array}$ & $\begin{array}{l}\text { Correlation with chronology } \\
\text { HOR_AA1 }[r]\end{array}$ \\
\hline HOR1 & 74 & 6.232 & 0.603 \\
HOR4 & 29 & 6.144 & 0.809 \\
HOR5 & 28 & 4.635 & 0.703 \\
HOR6 & 37 & 4.559 & 0.634 \\
HOR8 & 51 & 6.503 & 0.696 \\
HOR9 & 38 & 6.146 & 0.736 \\
HOR10 & 67 & 8.083 & 0.719 \\
HOR13 & 32 & 5.557 & 0.737 \\
HOR14 & 27 & 6.027 & 0.796 \\
HOR15 & 87 & 8.898 & 0.703 \\
HOR17 & 30 & 3.908 & 0.624 \\
HOR18 & 59 & 6.115 & 0.643 \\
HOR22 & 29 & 5.203 & 0.735 \\
HOR28 & 43 & 6.420 & 0.777 \\
HOR29 & 38 & 5.533 & 0.699 \\
HOR30 & 55 & 7.086 & 0.711 \\
HOR33 & 26 & 4.138 & 0.679 \\
HOR35 & 37 & 9.950 & 0.873 \\
HOR36 & 73 & 4.646 & 0.494 \\
HOR38 & 64 & 5.726 & 0.608 \\
HOR42 & 45 & 5.923 & 0.688 \\
HOR43 & 39 & 5.833 & 0.713 \\
\hline
\end{tabular}

Results of the relative dendrochronological dating of Horodnianka wood samples are presented in the block diagram (Figure 6). Dendrochronological analysis demonstrated that the trees had been felled within a relatively short time interval, only 22 yr. Moreover, distinct periods (time intervals) of introduction of the wood material into the palisades, marked with the ranges A-C in Figure 6, could be observed. The first period took place in the year 77, the second one in the years $83-85$, and the third represented the period 87-89 (all ranges given in relative years). The chronology produced was compared against the available chronologies constructed for oak from Poland and neighboring countries (Krapiec 2001; Zielski and Krąpiec 2004). Unfortunately, no synchronous position, enabling unequivocal dating, could be stated. The principal cause of the failure apparently consists in too few annual growth rings in the chronology. 


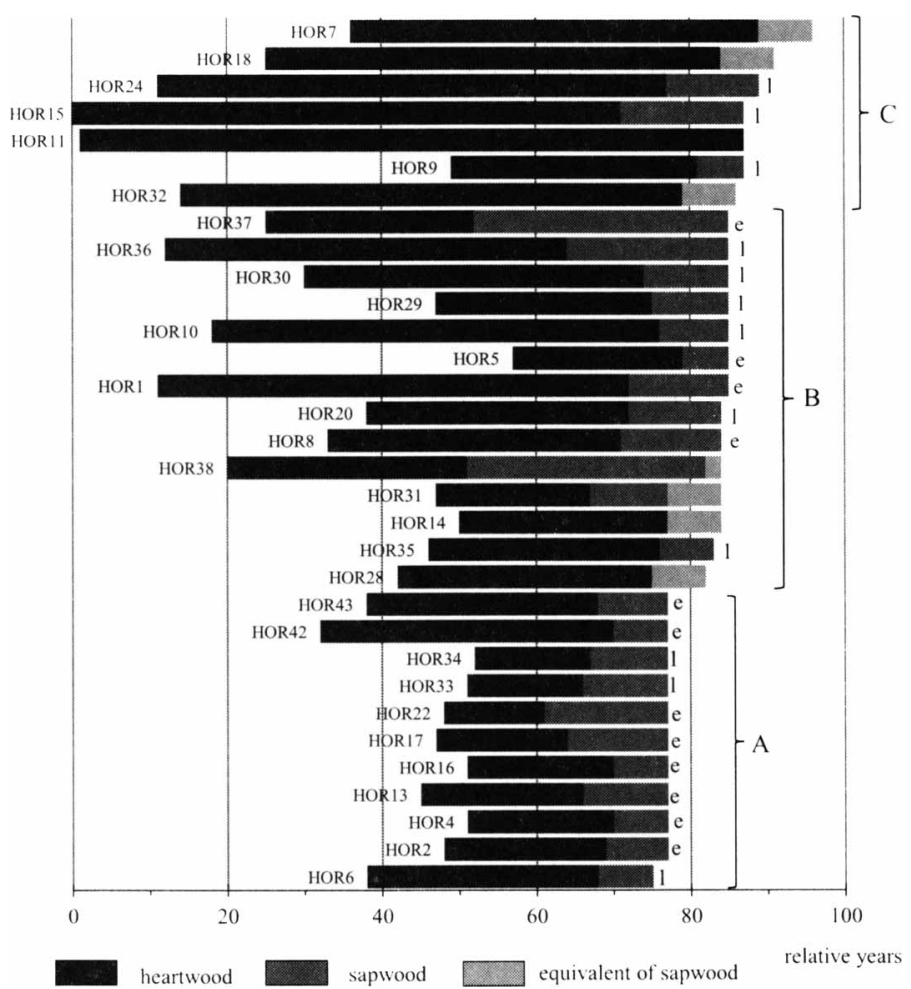

Figure 6 Correlation block diagram of dendrochronological sequences from Horodnianka forming the chronology HOR_AA1. The last growth ring with earlywood marked with $e$ and the last growth ring with latewood marked with $l$. There are 3 distinct periods of introduction of wood material into the palisade, marked with A-C.

The age of the palisade samples was determined via wiggle-matching, which has been frequently applied for dating relative dendrochronological sequences (Kruse et al. 1980; Linick et al. 1985; Pearson 1986; Krapiec 1992). The method has proven useful for wood from various epochs and regions (van der Plicht et al. 1995; Slusarenko et al. 2001; Vasiliev et al. 2001; Galimberti et al. 2004; Imamura et al. 2007).

From the HOR_AA1 chronology, 7 samples (HOR1, HOR9, HOR15, HOR30, HOR36, HOR37, HOR43) were selected for ${ }^{14} \mathrm{C}$ dating using LSC. The rings selected, together with their positions in the chronology, are presented in Figure 7 and Table 2. For HOR15, analysis was conducted on the inner trunk ( $i$ in Table 2), whereas for samples HOR 1, HOR9, HOR36, HOR37, HOR43, rings were taken from the external trunks ( $e$ in Table 2). Only for sample HOR30 was dating conducted on rings from the center of the trunk (rings 14-28). In every case, $15-30$ annual growth rings were ${ }^{14} \mathrm{C}$ dated.

For the Horodnianka wiggle-matching, the agreement index for the complete D_Sequence was $102.8 \%$, with $\mathrm{An}=26.7 \%(n=7)$, suggesting that the overall fit is acceptable. The ${ }^{1{ }^{14} \mathrm{C}}$ dating results of the 7 samples from the HOR_AAl chronology, after the dependent calibration (Figures 8 and 9), indicate that the oak trees outlining the chronology were felled in 870-795 cal BC. Also, cross-dating was obtained for sequences containing fewer tree rings (from 25 to 86). Some of the curves with longer sequences do not display any similarity with each other. They perhaps grew in unfavorable conditions, e.g. under canopy cover. Such trees often are characterized by zones of narrow tree rings 


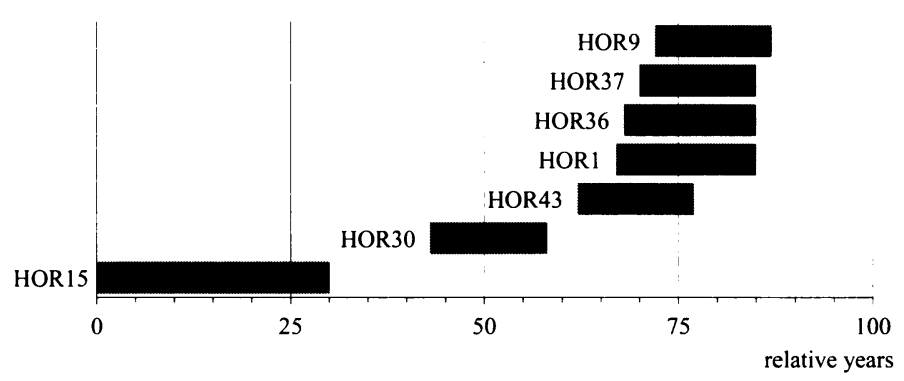

Figure 7 Selected tree-ring series used in the wiggle-matching

Table 2 Sample descriptions with conventional and calibrated ages of samples from Horodnianka. Age ranges determined with confidence levels of $68 \%$ and $95 \%$ using OxCal (Bronk Ramsey 2009).

\begin{tabular}{|c|c|c|c|c|c|c|}
\hline $\begin{array}{l}\text { Sample } \\
\text { description }^{\mathrm{a}}\end{array}$ & $\begin{array}{l}\text { Code }^{\mathrm{b}} \\
\text { (MKL-) }\end{array}$ & $\begin{array}{l}{ }^{14} \mathrm{C} \text { age } \\
\text { (BP) }\end{array}$ & $\begin{array}{l}\text { Cal age range } \\
(68.2 \%)\end{array}$ & $\begin{array}{l}\text { Cal age range } \\
(95.4 \%)\end{array}$ & $\begin{array}{l}\mathrm{Nr} \text { of } \\
\text { width } \\
\text { series }\end{array}$ & $\begin{array}{l}\mathrm{Nr} \text { of rings } / \\
\text { their position }\end{array}$ \\
\hline $\begin{array}{l}\text { HOR } 15 \text {, Quercus, } \\
\mathrm{w}-\mathrm{m}\end{array}$ & 678 & $2820 \pm 60$ & $1060-890$ BC (68.2\%) & $1130-820$ BC (95.4\%) & 87 & $30 \mathrm{i} / 1-30$ \\
\hline $\begin{array}{l}\text { HOR43, Quercus, } \\
\text { w-m }\end{array}$ & 677 & $2760 \pm 50$ & $\begin{array}{l}980-950 \mathrm{BC}(7.3 \%) \\
940-830 \mathrm{BC}(60.9 \%)\end{array}$ & $1020-800$ BC (95.4\%) & 39 & $15 e / 63-77$ \\
\hline 2HOR2, Pinus & 674 & $2740 \pm 50$ & $930-820$ ВС $(68.2 \%)$ & $1000-800$ BC (95.4\%) & 30 & - \\
\hline HOR25, Quercus & 683 & $2740 \pm 50$ & $930-820$ ВC (68.2\%) & $1000-800$ BC (95.4\%) & 96 & $15 \mathrm{e} /-$ \\
\hline $\begin{array}{l}\text { HOR30, Quercus, } \\
\mathrm{w}-\mathrm{m}\end{array}$ & 880 & $2690 \pm 40$ & $\begin{array}{l}895-865 \text { BC }(21.5 \%) \\
860-805 \text { BC }(46.7 \%)\end{array}$ & $920-790 \mathrm{BC}(95.4 \%)$ & 55 & $14-28 / 45-59$ \\
\hline $\begin{array}{l}\text { HOR 1, Quercus, } \\
\text { w-m }\end{array}$ & 675 & $2690 \pm 50$ & $\begin{array}{l}895-865 \text { BC }(21.9 \%) \\
860-805 \text { BC }(46.3 \%)\end{array}$ & $\begin{array}{l}970-950 \text { BC }(1.2 \%) \\
940-790 \text { BC }(94.2 \%)\end{array}$ & 74 & $18 \mathrm{e} / 68-85$ \\
\hline HOR 12, Quercus & 679 & $2690 \pm 50$ & $\begin{array}{l}895-865 \text { BC }(21.9 \%) \\
860-805 \text { BC }(46.3 \%)\end{array}$ & $\begin{array}{l}970-950 \text { BC }(1.2 \%) \\
940-790 \text { BC }(94.2 \%)\end{array}$ & 72 & $18 \mathrm{i} /-$ \\
\hline $\begin{array}{l}\text { HOR36, Quercus, } \\
\text { w-m }\end{array}$ & 681 & $2660 \pm 50$ & $\begin{array}{l}895-875 \text { BC }(11.0 \%) \\
850-790 \text { ВС }(57.2 \%)\end{array}$ & $920-760$ BC (95.4\%) & 73 & $17 \mathrm{e} / 69-85$ \\
\hline $\begin{array}{l}\text { HOR9, Quercus, } \\
\text { w-m }\end{array}$ & 676 & $2640 \pm 50$ & $\begin{array}{l}890-880 \text { ВC }(3.5 \%) \\
850-770 \text { ВC }(64.7 \%)\end{array}$ & $\begin{array}{l}920-750 \text { BC }(93.5 \%) \\
690-660 \text { BC }(1.9 \%)\end{array}$ & 38 & $15 \mathrm{e} / 73-87$ \\
\hline $\begin{array}{l}\text { HOR37, Quercus, } \\
\text { w-m }\end{array}$ & 682 & $2620 \pm 50$ & $840-760$ ВC $(68.2 \%)$ & $\begin{array}{l}910-740 \text { BC }(84.0 \%) \\
690-660 \text { BC }(5.0 \%) \\
650-590 \text { BC }(5.4 \%) \\
580-560 \text { BC }(1.0 \%)\end{array}$ & 60 & $15 \mathrm{e} / 71-85$ \\
\hline HOR 19, Quercus & 685 & $2610 \pm 50$ & $\begin{array}{l}840-760 \text { BC }(64.1 \%) \\
690-670 \text { BC }(4.1 \%)\end{array}$ & $\begin{array}{l}900-740 \mathrm{BC}(76.3 \%) \\
690-660 \mathrm{BC}((7.0 \%) \\
650-550 \mathrm{BC}(12.1 \%)\end{array}$ & 93 & $17 \mathrm{i} /-$ \\
\hline HOR2, Quercus & 680 & $2590 \pm 50$ & $\begin{array}{l}820-750 \text { BC }(52.7 \%) \\
690-660 \text { BC }(8.8 \%) \\
640-590 \text { BC }(6.6 \%)\end{array}$ & $\begin{array}{l}850-720 \text { BC }(60.5 \%) \\
700-530 \text { ВC }(34.9 \%)\end{array}$ & 68 & $15 \mathrm{i} /-$ \\
\hline
\end{tabular}

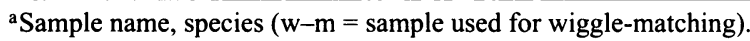

b Laboratory code of the Laboratory of Absolute Dating in Skała, Poland.

${ }^{\mathrm{c}}$ Number of tree rings used in wiggle-matching analysis and their position in the chronology: $i=$ internal annual growth (oldest ring), $e=$ external annual growth (the youngest ring).

and they record the climatic signal in annual growth sequences insufficiently. Dendrochronological dating of such trees is thus often not possible. Therefore, 5 samples were subjected to ${ }^{14} \mathrm{C}$ dating: MKL-674; MKL-679; MKL-680; MKL-683; MKL-685 (Table 2). The results indicate that these samples most probably originated from the same time period as the palisade elements analyzed. For the ash, elm, and pine wood, hetero-connection with the newly constructed oak chronology was applied, but, unfortunately, dendrochronological dating was unsuccessful. 


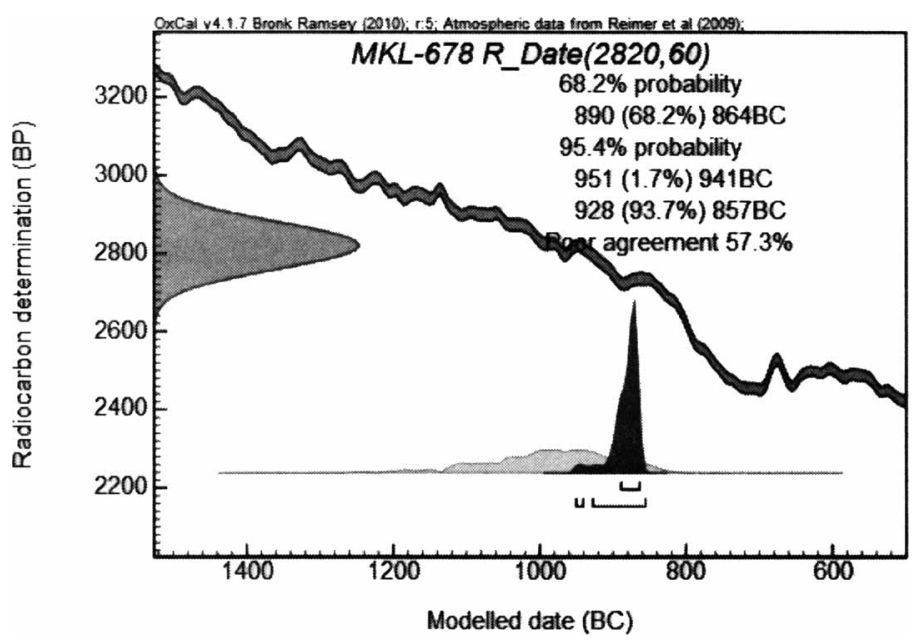

Figure 8 Calibrated position of the first ring of the oak chronology HOR_AA1

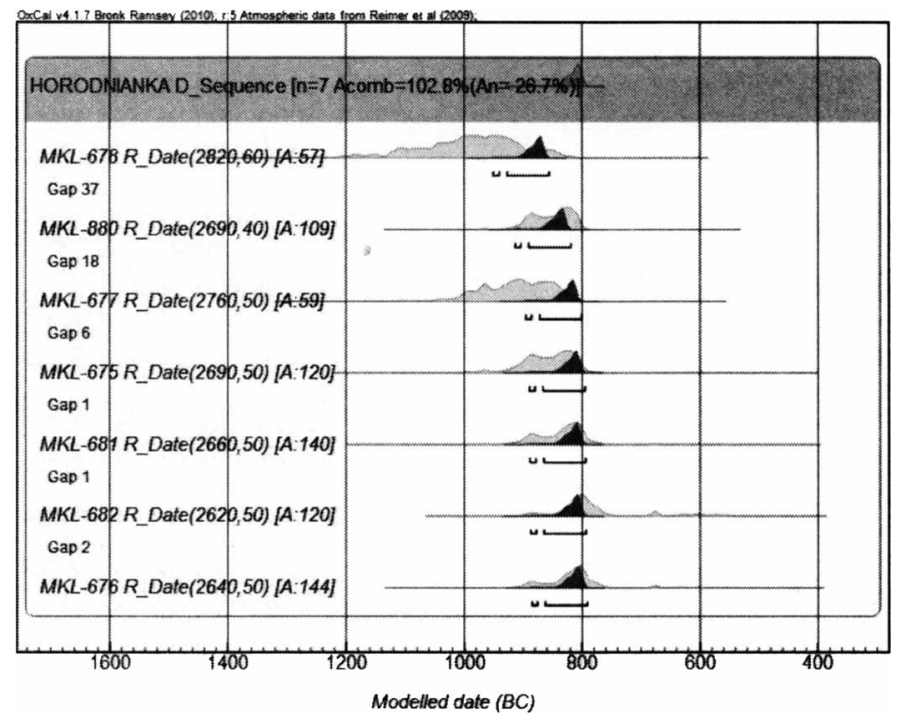

Figure $9{ }^{14} \mathrm{C}$ wiggle-matching of the floating oak chronology HOR_AA1

\section{CONCLUSION}

Combining the dendrochronological and ${ }^{14} \mathrm{C}$ analyses allowed for absolute dating of the timber structures fortifying the Horodnianka settlement. These structures were constructed from trees felled at the turn of the 10th and 9th centuries BC. The Horodnianka settlement is likely the northernmost defensive settlement of the Lusatian culture. More than 1300 pieces of pottery and over 3500 flinty archaeological finds were found that have been attributed to the Lusatian (Brzozowski et al. 2008; Bednarz and Brzozowski 2009). Therefore, Horodnianka proves to be a key site in the ancient history of northeastern Poland. Further archaeological data and absolute dating combined with Bayesian analysis should allow in the future for stratigraphy of this site and delineation of its settlement phases. This is especially true since only a small percentage of the entire 3-ha settlement has been excavated. 


\section{ACKNOWLEDGMENTS}

This study was supported by the Faculty of Geology, Geophysics and Environmental Protection, AGH, University of Science and Technology, Kraków, as a part of statutory project nr 11.11.140.560, Absolute Dating Laboratory in Skała and General Directorate for National Roads and Motorways (GDDKiA). The research also forms part of the PhD thesis of Monika Bolka, MSc Eng.

\section{REFERENCES}

Baillie MGL, Pilcher JR. 1973. A simple crossdating program for tree-ring research. Tree-Ring Bulletin 33: 7-14.

Bednarz M, Brzozowski J. 2009. Sprawozdanie z ratowniczych badań wykopaliskowych w Horodniance, stanowisko nr 12 (AZP 26-86/72) gmina Suchowola, powiat sokólski, województwo podlaskie, na trasie budowy obwodnicy Sztabina [Report on an archaeological rescue works in Horodnianka, the site no. 12 (AZP 26-86/72) Suchowola municipality, sokólski district, podlaskie voivodship, from construction the ring road around the town Sztabin]. Sztabin-Suwałki. p 1-10. In Polish.

Bronk Ramsey C. 2009. Bayesian analysis of radiocarbon dates. Radiocarbon 51(1):337-60.

Bronk Ramsey C, van der Plicht J, Weninger B. 2001. 'Wiggle-matching' radiocarbon dates. Radiocarbon 43(2A):381-9.

Brzozowski J, Ejdulis A, Maskowicz R, Siemaszko J. 2008. Wyniki archeologicznych badań rozpoznawczych w ciągu drogi krajowej nr 8 na trasie projektowanej obwodnicy $\mathrm{m}$. Sztabin, maszynopis $\mathrm{w}$ archiwum Muzeum Okrgowego w Suwałkach [Results of archaeological reconnaissance surveys within the national road no. 8 on the proposed ring road around the town Sztabin, typescript in the archives of the Regional Museum in Suwałki]. In Polish.

Galimberti M, Bronk Ramsey C, Manning SW. 2004. Wiggle-match dating of tree-ring sequences. Radiocarbon 46(2):917-24.

Holmes RL. 1999. User's Manual for Program COFECHA. Laboratory of Tree-Ring Research, University of Arizona, Tucson.

Imamura M, Ozaki H, Mitsutani T, Niu E, Itoh S. 2007. Radiocarbon wiggle-matching of Japanese historical materials with a possible systematic age offset. Radiocarbon 49(2):331-7.

Krawczyk A, Krapiec M. 1995. Dendrochronologiczna baza danych [Dendrochronological database]. Materiały II Krajowej Konferencji: Komputerowe wspomaganie badañ naukowych [Proceedings of The Second Polish Conference: Computers in Scientific Research]. Wrocław. p 247-52. In Polish.

Krąpiec M. 1992. Skale dendrochronologiczne pónego holocenu południowej i centralnej Polski [Dendrochronological scales of the Late Holocene of southern and central Poland]. Kwartalnik $A G H$ - Geologia 18(3):37-119. In Polish.

Krapiec M. 1998. Oak dendrochronology of the Neohol- ocene in Poland. Folia Quaternaria 69:5-134.

Krapiec M. 2001. Holocene dendrochronological standards for subfossil oaks from the area of southern Poland. Studia Quaternaria 18:47-63.

Krąpiec M, Walanus A. 2011. Application of the triplephotomultiplier liquid spectrometer Hidex 300SL in radiocarbon dating. Radiocarbon 53(3):543-50.

Kruse HH, Linick TW, Suess HE, Becker B. 1980. Computer-matched radiocarbon dates of floating tree-ring series. Radiocarbon 22(2):260-6.

Linick TW, Suess HE, Becker B. 1985. La Jolla measurements of radiocarbon in south German oak tree-ring chronologies. Radiocarbon 27(1):20-32.

Pearson GW. 1986. Precise calendrical dating of known growth-period samples using a 'curve fitting' technique. Radiocarbon 28(2A):292-9.

Reimer PJ, Baillie MGL, Bard E, Bayliss A, Beck JW, Blackwell PG, Bronk Ramsey C, Buck CE, Burr GS, Edwards RL, Friedrich M, Grootes PM, Guilderson TP, Hajdas I, Heaton TJ, Hogg AG, Hughen KA, Kaiser KF, Kromer B, McCormac FG, Manning SW, Reimer RW, Richards DA, Southon JR, Talamo S, Turney CSM, van der Plicht J, Weyhenmeyer CE. 2009. IntCal09 and Marine09 radiocarbon age calibration curves, 0-50,000 years cal BP. Radiocarbon 51(4): 1111-50.

Skripkin VV, Kovalyukh NN. 1994. An universal technology for oxidation of carbon-containing materials for radiocarbon dating. Conference on Geochronology and Dendrochronology of Old Town's and Radiocarbon Dating of Archaeological Findings. 31 October4 November 1994, Vilnius University Press. p 37-42.

Slusarenko IY, Christen JA, Orlova LA, Kuzmin YV, Burr GS. 2001. ${ }^{14} \mathrm{C}$ wiggle matching of the "floating" tree-ring chronology from the Altai Mountains, southern Siberia: the Ulandryk- 4 case study. Radiocarbon 43(2A):425-31.

Vasiliev SS, Bokovenko NA, Chugunov KA, Dergachev VA, Sementsov AA, Sljusarenko JU, Zaitseva GI. 2001. Tree-ring, "wiggle-matching" and statistics in the chronological studies of Scythian Age sites in Asia. Geochronometria 20:61-8.

van der Plicht J, Jansma E, Kars H. 1995. The "Amsterdam Castle": a case study of wiggle-matching and the proper calibration curve. Radiocarbon 37(3):965-8.

Walanus A. 2005. Program Quercus. Instrukcja obsługi [Program Quercus. User's manual]. Kraków. In Polish.

Zielski A, Krąpiec M. 2004. Dendrochronologia. Warsaw: PWN. In Polish. 